\title{
The Drosophila segmentation gene runt encodes a novel nuclear regulatory protein that is also expressed in the developing nervous system
}

\author{
Mary A. Kania, ${ }^{1}$ Andrea S. Bonner, ${ }^{2}$ Joseph B. Duffy, ${ }^{1}$ and J. Peter Gergen ${ }^{2,3}$ \\ ${ }^{1}$ Department of Biochemistry and Molecular Biology, The University of Texas M.D. Anderson Cancer Center, Houston, Texas \\ 77030 USA; ${ }^{2}$ Department of Biochemistry and Cell Biology, State University of New York at Stony Brook, Stony Brook, New \\ York 11794 USA
}

Generation of the anterior-posterior body pattern in the Drosophila embryo requires the activity of the segmentation genes. The segmentation gene runt has been classified as one of the primary pair-rule genes because of the pivotal role it plays in regulating the expression of other pair-rule genes. Here, we present the structure of this gene and describe the pattern of runt protein expression during embryogenesis. The deduced protein sequence shows no obvious overall homology with any sequences in the data base. The absence of an identifiable transcription factor motif (e.g., homeo box, zinc finger, leucine zipper, or helix-loop-helix) makes runt different from the other early-acting segmentation proteins. A runt-specific polyclonal antibody was generated and used to demonstrate that the subcellular location of the protein is in the nucleus. Doublestaining immunolocalization experiments were used to determine the overlap of the runt protein pattern with the patterns of the pair-rule genes hairy (h), even-skipped (eve), and fushi tarazu (ftz). We found that the patterns of runt and hairy are complementary. Their phasing is shifted anteriorly by two cell diameters with respect to the complementary eve and ftz patterns. Experiments with the runt antibody also indicated that the protein is present throughout embryogenesis and is expressed extensively in the developing central and peripheral nervous system.

[Key Words: Drosophila; segmentation gene; nuclear protein; neurogenesis]

Received June 11, 1990; revised version accepted August 2, 1990.

Segmentation in Drosophila offers a unique opportunity to investigate embryonic pattern formation. Extensive genetic studies have identified many genes that are required for normal segmentation, and both molecular and genetic approaches have yielded significant insight into this process. The segmental primordia are established by the action of the gap and pair-rule segmentation genes during the blastoderm stage of embryogenesis. These genes respond to coarse gradients of maternal information present in the egg and act to subdivide the body of the embryo into its initial metameric pattern. Molecular analyses have indicated that fundamental aspects of this process are accomplished through a hierarchy of regulatory interactions between genes encoding transcriptional regulatory proteins. All of the gap gene proteins characterized to date encode nuclearly localized proteins. The proteins of the gap genes Krüppel $(K r)$, hunchback $(h b)$, and knirps (kni) all contain zinc finger DNAbinding motifs (Rosenberg et al. 1986; Tautz et al. 1987; Nauber et al. 1988). Several studies demonstrated that these gap proteins bind to DNA in vitro. The gap proteins act to regulate the expression of each other (Jäckle

\footnotetext{
${ }^{3}$ Corresponding author.
}

et al. 1986; Mohler et al. 1989; Pankratz et al. 1989) and also play a critical role in generating the periodic expression patterns of the pair-rule genes (Carroll and Scott 1986; Frasch and Levine 1987; Howard 1988; Ingham and Gergen 1988). In vitro binding sites for the $K r, h b$, and kni gap proteins have been identified in the promoter regions of some of the relevant genes (Pankratz et al. 1989, 1990; Stanojevic et al. 1989; Treisman and Desplan 1989). These several observations suggest strongly that the important regulatory roles the gap genes play in segmentation are mediated by their proteins acting as DNA-binding transcription factors.

Similar arguments suggest strongly that the functions of the pair-rule genes also involve the regulation of transcription. The pair-rule genes act to regulate each other (Carroll and Scott 1986; Howard and Ingham 1986; Ingham and Gergen 1988), as well as to regulate the expression of the later-acting segment-polarity genes (DiNardo and O'Farrell 1987). Several lines of evidence suggest that these regulatory effects are mediated at the transcriptional level. The (even-skipped) (eve), fushi tarazu (ftz), and hairy ( $h$ ) proteins are localized in the nuclei of expressing cells (Carroll and Scott 1985; Frasch et al. 1987; Carroll et al. 1988; Hooper et al. 1989). The 
eve and $f t z$ proteins, as well as that encoded by the paired (prd) gene, all contain the homeo box DNAbinding domain (Laughon and Scott 1984; Frigerio et al. 1986; Macdonald et al. 1986; Frasch et al. 1987). In vitro-expressed forms of all three of these homeo boxcontaining pair-rule proteins bind DNA (Desplan et al. 1988; Hoey and Levine 1988; Treisman et al. 1989). An additional important piece of evidence that these proteins function as transcriptional regulators comes from the observations that $f t z$ activates transcription from promoters containing consensus homeo domainbinding sites both in Drosophila cells (Jaynes and O'Farrell 1988) and in yeast (Fitzpatrick and Ingles 1989). The $h$ protein, which plays an important role in regulating the expression of eve and $f t z$, does not have a homeo box but, instead, has homology to an amphipathic helixloop-helix motif present in a variety of other transcription factors (Rushlow et al. 1989).

Here, we investigate the protein encoded by the pairrule gene runt. This gene plays a key role in regulating the expression of all other pair-rule genes examined to date (Carroll and Scott 1986; Frasch and Levine 1987; Ingham and Gergen 1988; Carroll and Vavra 1989; Hooper et al. 1989). Therefore, defining the function of runt and the mechanism by which it acts to regulate other genes is central to understanding the process of segmentation. In this paper, we show that runt encodes a protein without obvious homology to recognized motifs for DNA binding or protein-protein interaction. However, consistent with a potential role as a transcriptional regulator, we found that this protein is localized in the nucleus. We determined the pattern of runt expression relative to other pair-rule genes. These results are discussed in the context of the known regulatory interactions between these genes. Interestingly, we also found that the runt protein is expressed extensively in both the central nervous system (CNS) and peripheral nervous system (PNS) of the developing embryo.

\section{Results}

\section{Organization of the runt transcription unit}

The runt locus encodes a $2.6-\mathrm{kb} \operatorname{poly}(\mathrm{A})^{+}$RNA that is most abundantly expressed at the blastoderm stage of embryogenesis (Gergen and Butler 1988). We used S1 nuclease protection, primer extension, and DNA sequence analyses to determine the structure of this transcription unit. A schematic summary of these results is shown in Figure 1. S1 nuclease protection experiments done with embryo RNA indicate that runt RNA is comprised of two principal exons, 1.5 and $0.95 \mathrm{~kb}$ in size (Fig. 2A). The localization of the intron was determined from the sequence of the genomic and cDNA clones. The intron is 409 nucleotides in length, is flanked at its $5^{\prime}$ and 3 ' boundaries by the consensus GT. . .AG nucleotides, respectively, and agrees well (21 of 23 positions; data not shown) with a consensus sequence for intron boundaries (Mount 1982).

The sequence spanned by the cDNA clone inserts (2454 nucleotides; see below) should represent almost

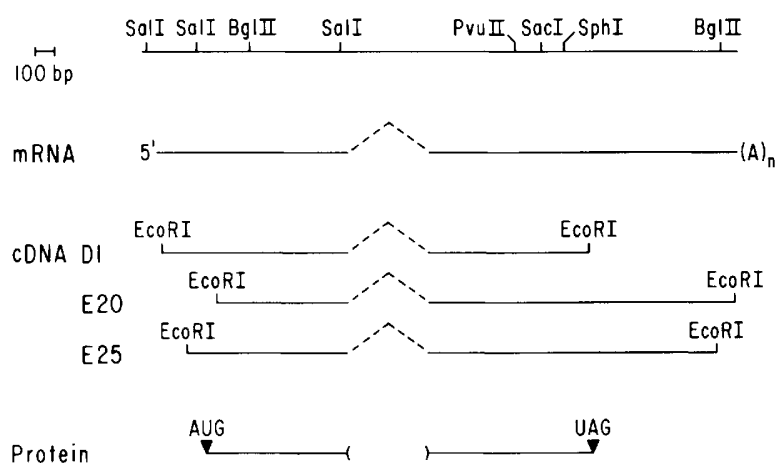

Figure 1. Schematic summary of the runt structural gene. The segment of genomic DNA containing the runt structural gene is represented by the top-most line. The locations of several restriction endonuclease cleavage sites are indicated above the line. The mRNA is transcribed $5^{\prime}$ to $3^{\prime}$, left to right, as shown. The solid line indicates regions contained in the mature mRNA; the dashed line represents the intervening sequence. The extents of mRNA contained within three different cDNAs are indicated below this. The EcoRI sites shown at the ends of these clones are present due to the method of their construction. The bottom line shows the placement of the runt ORF relative to the mRNA and the different cDNA clones.

all of the 2.6-kb runt mRNA. The 3 '-most cDNA clone (E20) contains the consensus AATAAA signal for poly $(A)$ tail addition 18 nucleotides upstream of a string of 17 As (Fig. 3). This suggests that this cDNA extends to the $3^{\prime}$ end of the transcription unit. Primer extension experiments were carried out to determine the extent of 5 ' sequence not contained within the cDNAs. The results reveal a single predominant reverse transcription product that extends 30 nucleotides beyond the end of the sequence contained in the $5^{\prime}$-most cDNA clone (D1, see Fig. 2B). Figure 2B also shows the genomic DNA sequence in this region. There are no good consensus splice acceptor sites within this 30 nucleotides of upstream sequence, suggesting that transcription initiates at the position indicated by the reverse transcription product. The sequence around the putative cap site is in perfect concordance (7 of 7) with a consensus derived from other Drosophila genes (Hultmark et al. 1986). There is an AT-rich TATA box-like region (Fig. 3) 30 nucleotides upstream of the putative cap site. Further evidence that this cap site corresponds to the site of transcript initiation comes from in vitro transcription experiments with Drosophila embryo extracts. These reveal a single run-off transcription product that initiates at or near the site indicated by our primer extension analysis (J. Topol and C. Parker, pers. comm.). On the basis of these observations, we conclude that the runt mRNA is comprised of only two exons and that transcription initiates at the nucleotide designated +1 in Figure 3 .

\section{Deduced sequence of the runt protein}

We have used both cDNA and genomic clones to determine the sequence of the runt gene. This sequence is shown in Figure 3, where we included 67 nucleotides of 


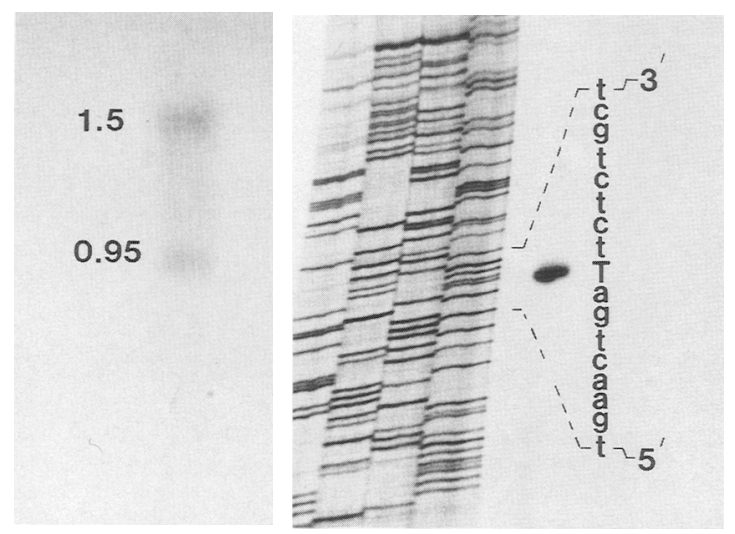

Figure 2. Structure of the runt mRNA. (A) Results of an S1 nuclease protection experiment. Total RNA from 2- to 4-hr embryos was hybridized with an $8-\mathrm{kb}$ segment of genomic DNA extending from a BamHI site, $2.5 \mathrm{~kb}$ upstream of the start site of transcription, to a HindIII site, $2.9 \mathrm{~kb}$ downstream of the $\mathrm{pA}^{+}$addition site, and digested with $\mathrm{S} 1$ nuclease. Protected DNA fragments were separated by alkaline gel electrophoresis and detected by Southern blot analysis with a radiolabeled genomic DNA probe. The sizes of the protected fragments were determined relative to the $1-\mathrm{kb}$ ladder (BRL). The blank lane (right) is a control where no Drosophila RNA was added to the hybridization. $(B)$ Sequencing ladder of a cloned segment of genomic DNA run in parallel with the products of a reverse transcription primer extension reaction. Total RNA from 2- to 4-hr embryos was used as template for the primer extension reaction. An oligonucleotide extending from +171 to +155 (see Fig. 3 |, $5^{\prime}$ to $3^{\prime}$ on the antisense strand, was used as the primer for both reactions. This primer was end-labeled with ${ }^{32} \mathrm{P}$ for the reverse transcription reaction. The sequencing ladder is labeled as a result of the incorporation of ${ }^{35} \mathrm{~S}$-labeled dATP during the sequencing reaction. The antisense strand sequence around the position of the single primer extension product is indicated at right. The sequence $3^{\prime}$-TAGTCAA- $5^{\prime}$ is complementary to the sense strand cap site consensus $5^{\prime}-\mathrm{ATCA}(\mathrm{G} / \mathrm{T}) \mathrm{T}(\mathrm{C} / \mathrm{T})-3^{\prime}$ proposed by Hultmark et al. (1986).

5'-flanking genomic DNA sequence and omitted the intron that would interrupt the sequence between nucleotides 958 and 959 (as they are numbered in Fig. 3). The longest open-reading frame (ORF) encoded by this sequence initiates at the first ATG in the sequence, at nucleotide 253, and extends for 509 codons. The codon usage of this ORF is typical for Drosophila, and the longest ORF in either of the other two reading frames is only 70 amino acids. This strongly suggests that this ORF corresponds to the runt protein.

In vitro translation of mRNAs synthesized from two different cDNA templates (E25, ED) that span the predicted ORF yields a $68-\mathrm{kD}$ protein (not shown). The apparent size of this protein is significantly larger than the $53 \mathrm{kD}$ predicted for this ORF. The beginning and end of the ORF responsible for this $68-\mathrm{kD}$ protein were mapped by translating truncated in vitro-synthesized mRNAs. These results were consistent with the sites of initiation and termination shown in Figure 3 (data not shown).
Comparison of the in vitro translation product with a full-length, nonfusion protein made in bacteria provided stronger evidence that the predicted first AUG is utilized. The recombinant DNA construction used to generate this bacterial form of the runt protein was designed to initiate translation at the predicted first AUG. These proteins both migrated at $68 \mathrm{kD}$ on SDS gels and also gave identical partial digestion patterns with $\mathrm{V} 8$ protease (data not shown). On the basis of these results, we conclude the runt mRNA encodes the ORF shown in Figure 3. Experiments described below demonstrate that antibodies directed against this ORF recognize the runt protein in Drosophila embryos. The anomalous migration of this protein (68 vs. $53 \mathrm{kD}$ predicted) is most likely due to its unusual amino acid composition (e.g., $16 \%$ alanine, $14 \%$ serine, $9 \%$ proline). Similar observations have been made for many other proteins, including several involved in segmentation /Carroll and Scott 1986; Gaul et al. 1987; Ollo and Maniatis 1987; Krause et al. 1988).

A search of the Swiss Protein Data Base (release 11) with the FASTP algorithm revealed no sequences of obvious overall homology or relatedness to the deduced runt protein sequence. We searched carefully for and failed to find any homology between the runt sequence and the zinc finger and homeo box DNA-binding motifs found in other segmentation genes. We also found no evidence of homology to the leucine zipper or the amphipathic helix-loop-helix motifs similar to those described for a variety of transcriptional regulatory proteins.

A significant difference between runt and other characterized gap and pair-rule proteins is the prediction that the runt protein has an amino-terminal signal sequence, which could target it for translocation across the membrane of the endoplasmic reticulum (see Fig. 3). An unusual aspect of this predicted signal sequence is that 15 of the 23 hydrophobic residues are alanine. Twelve of these are in a homopolymeric run, extending from position 18 to position 29 in the protein sequence. This type of arrangement is unprecedented in known signal sequences; however, there is precedent for homopolymeric stretches similar to this in the nonsecreted segmentation proteins eve and engrailed (en). Therefore, the possibility exists that the amino-terminal localization of this element is coincidental and that the predicted signal sequence might not be functional.

\section{Localization of runt protein in the blastoderm embryo}

We generated a runt-specific antiserum to characterize the in vivo localization of the protein. This antiserum was raised against a $\beta$-galactosidase fusion protein containing the entire runt ORF (for details of construction and for purification of runt specific antibodies, see Materials and methods). This antibody reveals a pair-rule pattern of seven stripes of staining in blastoderm-stage Drosophila embryos (Fig. 4A). This staining is runt-dependent, as it is eliminated in embryos mutant for a transcript null allele (runt ${ }^{L B 5}$; Fig. 4B). The staining observed in blastoderm-stage embryos suggests strongly 
CAT COG CCA CTG OCC AAG TCC TCS GCC TCC TCE GTG TCS OCA MT OCC AAT CCA TOG GTG GCC ACC ACC TCC HIS Pro Ala Lou Ala Lys Ser Ser Ala Ser Ser Val Ser Pro Asn Pro Asn Pro Ser Val Ala Thr Ser Ser

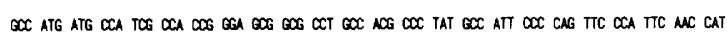
Ala wat Pro Ser Pro pro gly Ala Ala Pro Ala Thr Pro Tyr Ala lle Pro Gin Phe Pro Phe Asn His

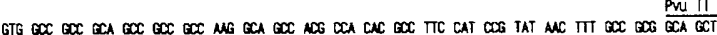
Val Ala Ala Ala Ala Ala Ala Lys Ala Ala Thr Pro His Ala the His Pro Tyr Ast Phe Ala Ala Ala Ala

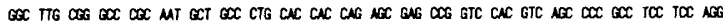
Gly Lou arg Ala arg Asn Ala Ala Lou HIs His Gin Ser Glu Pro Val His Val Ser Pro ala Ser Ser Arg

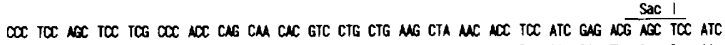

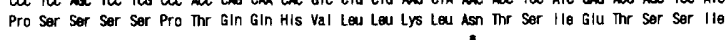

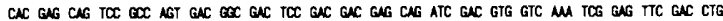
His Glu Gin Sor Ala Ser ASO Gly ASD Ser ASD ASD Glu GIn He ASD val val Lys Ser Glu phe ASD Lou

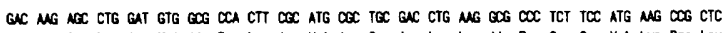

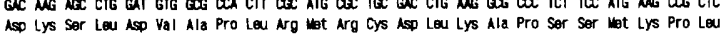

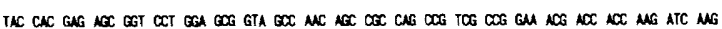

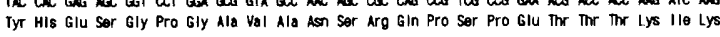

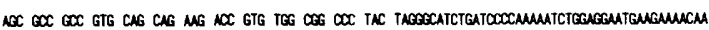
Ser Ala Ala Val Gin Gin Lys Ihr val Iro Arg Pro Tyr --

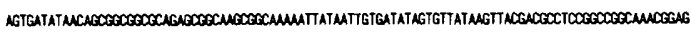

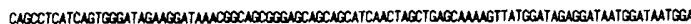

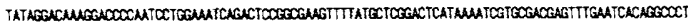

2111

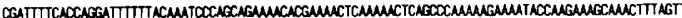

2207

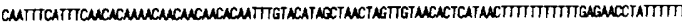

2303

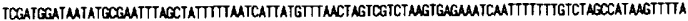

2399

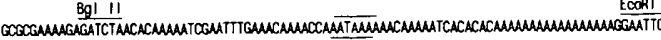

Figure 3. Sequence of the runt gene. The sense strand sequence of runt DNA, extending from 67 nucleotides upstream of the start of transcription to the $3^{\prime}$ end of cDNA E20, but not including the sequence of the intron, is shown. All of cDNA E20 (+ 300 to + 2492) was sequenced on both strands. Regions of cDNAs D $1(+30$ to +1760$)$ and E25 $(+156$ to +2384$)$ were used to extend the 5 ' sequence and confirm several other regions. The sequence from -67 to +239 was determined from analysis of genomic DNAs, as was the exact site of the intron (959/960). The transcript initiation site is denoted as position +1. An AT-rich TATA-like box located 30 nucleotides upstream of +1 is underlined and overlined. An AATAAA sequence 18 nucleotides upstream of the presumptive poly(A) tail is also indicated in this manner. Recognition sites for several restriction endonucleases are indicated above the sequence. Sequence polymorphisms are also indicated above the sequence. The deduced amino acid sequence of the longest ORF encoded by the runt mRNA is shown below the DNA sequence. In those cases where DNA sequence polymorphisms alter the amino acid sequence, the difference is indicated below. Potential sites of $N$-linked glycosylation $(\mathrm{NxT} / \mathrm{S})$ are indicated by asterisks $(*)$ below the protein sequence. The two regions underlined with dashes (63-93 and 287-314) correspond to predicted good PEST regions (scores of 13.68 and 8.38, respectively; Rogers et al. 1986). The two regions with solid underlines (193-200 and 252-256) are homologous to a proposed ATP-binding motif (Walker et al. 1982). This motif is comprised of two regions, termed the A and B boxes, the first (A box) of which is most important. The runt sequence from residues 193 to 200 (GrsgrGKS/ conforms exactly to the A box motif (GxxxxGKT/ S). The B box motif is comprised of four hydrophobic residues preceding an aspartic acid residue. When this motif is present, it is found from 40 to 200 residues to the carboxy-terminal side of the A box. The best match to this in runt is the region with the sequence PAWLD, located 51 residues to the carboxy-terminal side of the putative A box.

that the subcellular localization of the runt protein is in the nucleus. To distinguish more definitively between the possibility of intranuclear versus nuclear membrane localization, we compared the runt staining pattern with that of Drosophila lamin, which is nuclear membrane associated. As a control for another intranuclear protein, we also examined the localization pattern of the eve protein. Surface views of staining patterns with these three antisera show clearly that the runt pattern (Fig. $5 \mathrm{~A}$ ) resembles that of eve (Fig. 5C) more closely than that of lamin (Fig. 5B). We therefore conclude that the runt protein is localized within nuclei of blastodermstage embryos.

We performed double-label immunolocalization experiments to determine the phasing of the pattern of runt expression relative to other segmentation genes. In blastoderm embryos double-stained for runt and $h$, the stripes of $h$ accumulation (indicated by brown) are anterior to the stripes of runt accumulation (blue, Fig. 6A). These two patterns are complementary, and no clear 

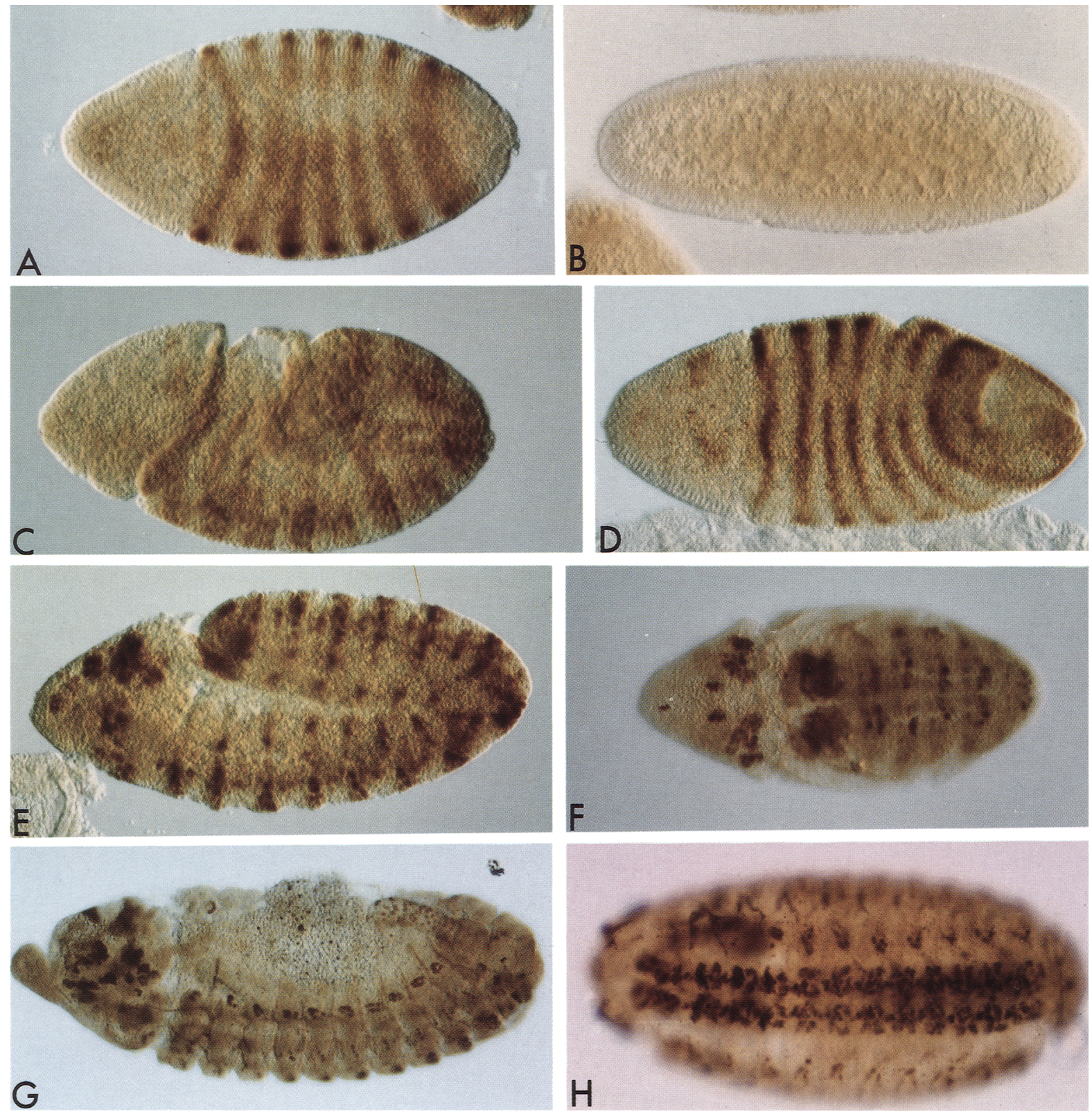

Figure 4. Pattern of runt expression. Photomicrographs of Drosophila embryos stained with affinity-purified rabbit anti-runt antibodies are shown. Immunoreactivity is indicated by a brown staining reaction. This was obtained by use of a biotin-conjugated anti-rabbit secondary antibody and the HRP version of the ABC immunodetection kit (Vector Laboratories). All embryos are oriented with their anterior end to the left. $(A)$ and $(B)$ are both lateral views of blastoderm-stage embryos. The embryo in $(A)$ is wild type; that in $(B)$ is hemizygous mutant for a runt allele that produces no mRNA (LB5). Lateral views of wild-type embryos during mid-germ-band extension, fully extended, and after germ-band retraction, are shown in $(C),(E)$, and $(G)$, respectively. $(D)$ and $(F)$ are dorsal views of mid- and fully germ band-extended embryos. $(H)$ is a ventral view of a germ band-retracted embryo.

gaps of nonexpressing cells are evident within the region of the embryo that contains the stripes. This complementarity is retained until the stage at which $h$ expression disappears. A different result is obtained in embryos double-stained for runt and eve. The stripes of eve accumulation (blue) lie anterior to those of runt, but overlap them partially (brown; Fig. 6B). Normal eve and runt stripes would be four nuclei wide at this stage. Two rows of eve-expressing (blue) nuclei are evident anterior to an overlap region comprised of two rows of nuclei that express both of these proteins. Posterior to this are two rows of runt-expressing (brown) nuclei, followed by two rows of nuclei located between the posterior margin of each runt stripe and the anterior margin of the next eve stripe that do not express detectable levels of either protein. We also performed double-staining experiments to determine the relative phasings of runt and $f t z$. These patterns also overlap, but the runt stripes are more ante- 


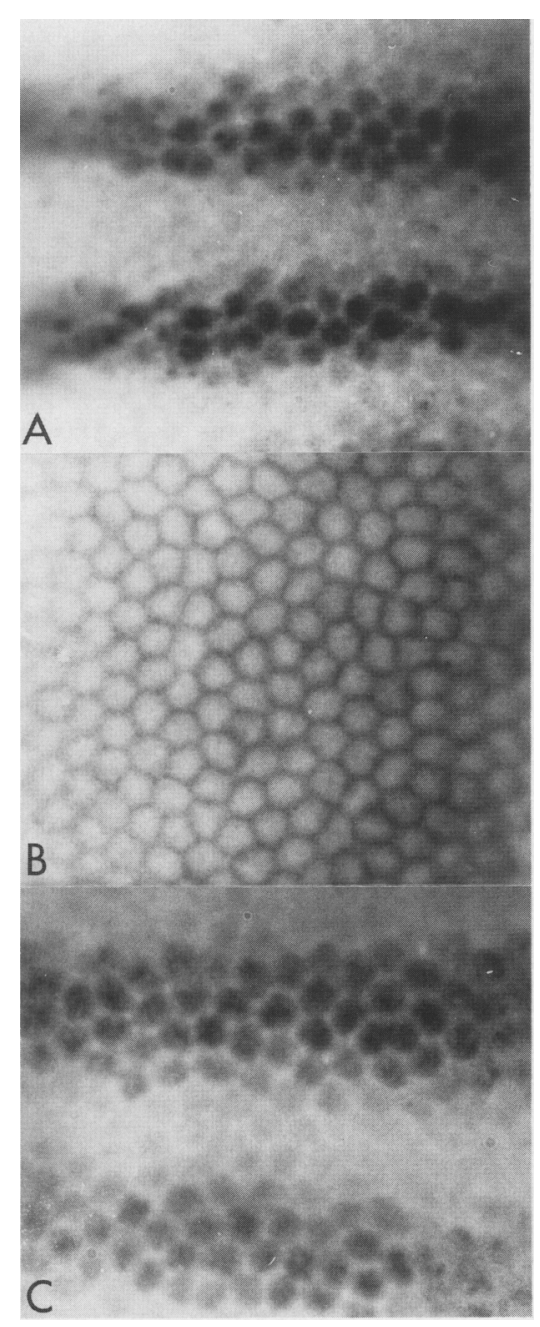

Figure 5. The runt protein is localized within blastoderm nuclei. Surface views of blastoderm-stage embryos stained with antibodies that detect runt $|A|$, nuclear lamin $(B)$, and eve proteins $(C)$ are shown. All three antisera are rabbit polyclonals. Immunoreactivity was detected with biotin-conjugated antirabbit secondary antibodies and the HRP version of the Vector Laboratories ABC kit.

rior (Fig. 6C). Two rows of runt-expressing nuclei (brown) lie anterior to each region of overlap, and two rows of $f t z$-expressing nuclei (blue) lie posterior to each region. The gaps of unstained nuclei consistently appeared larger in the runt-ftz double-stained embryos than in the runt-eve embryos. This probably reflects the fact that for $f t z$, the nuclei not contained in the overlap are those from the posterior half of each stripe. These are the nuclei that initially stain more weakly for $f t z$ and lose $f t z$ expression when the stripes narrow (Carroll and Scott 1985). The opposite is true for eve, where eve-expressing nuclei not in the runt overlap region stain more strongly and retain expression as the eve stripes narrow (Frasch and Levine 1987). In conclusion, the runt and $h$ patterns are complementary and are phase-shifted anteriorly with respect to the complementary eve and $f t z$ patterns. The relative phasing of these pair-rule patterns of expression is maintained along the length of the antero-posterior axis.

\section{Postblastoderm expression of the runt protein}

In early germ band-extending embryos, the pattern of runt mRNA accumulation undergoes a transition from a pair-rule to a segmental pattern of expression and is also expressed in a dorsal patch of cells in the head /Gergen and Butler 1988). These patterns are clearly evident in embryos stained with the runt antibody (Fig. 4). The expression of runt in the head of early germ band-extending embryos is composed of two regions of staining. There is a dorso-lateral group of $\sim 10$ cells and a ventral group of 7 less intensely stained cells (Fig. 4C,D). Expression in this region is much more complex by the time of full germ-band extension, with four pairs of clusters of staining cells (Fig. 4E,F). At this stage in the segmented regions of the body, the staining intensifies within individual cells just off the ventral midline and fades laterally in each segment. The stained cells along the ventral midline (approximately six per segment) are of different sizes, have varied staining intensities, and probably correspond to neuroblasts (Fig. 4F). During germ-band retraction, this putative neural expression of runt becomes more evident, with accumulation in regions corresponding to both the CNS and PNS. Upon completion of germ-band retraction, $\sim 50$ cells per hemisegment, located ventrally in a region corresponding to the developing CNS, are stained with the runt antibody (Fig. $4 \mathrm{H}$ ). Three more laterally situated clusters of runt-expressing cells are found in regions that would correspond to PNS (Fig. 4G). These postblastoderm patterns of antibody staining are due to accumulation of runt protein as they are eliminated in runt ${ }^{L B 5}$ mutant embryos. At these later stages, the protein appears to be accumulating primarily in the nuclei of expressing cells.

We examined the pattern of accumulation in embryos mutant for the Notch gene to demonstrate that this later runt expression is in neural cells. In these mutant embryos, the cells in the neurogenic region that would normally take on epidermal fates instead become neuroblasts. The presence of more runt-expressing cells in these embryos in regions corresponding to both CNS and PNS (Fig. 7A) provides evidence that runt is being expressed in cells of neural origin. The expanded runt expression in these embryos is still organized into a fairly coherent pattern. This is most evident in the PNS. For example, runt is normally expressed in three cells in a region corresponding to the $\mathrm{V}^{\prime}$ cluster (Fig. $7 \mathrm{~B}$ ). In Notch- embryos, a cluster of runt-expressing cells is still evident in this region but is now expanded to include from 12 to 18 cells (Fig. 7C). This observation is consistent with an "equivalence group" model of neuroblast determination. In this model, groups of cells are prespecified such that they have the potential to become different types of neuroblasts (e.g., runt expressing). The neurogenic genes normally act to ensure that the proper number of neuroblasts is produced from these groups and that other cells in the group are inhibited from en- 


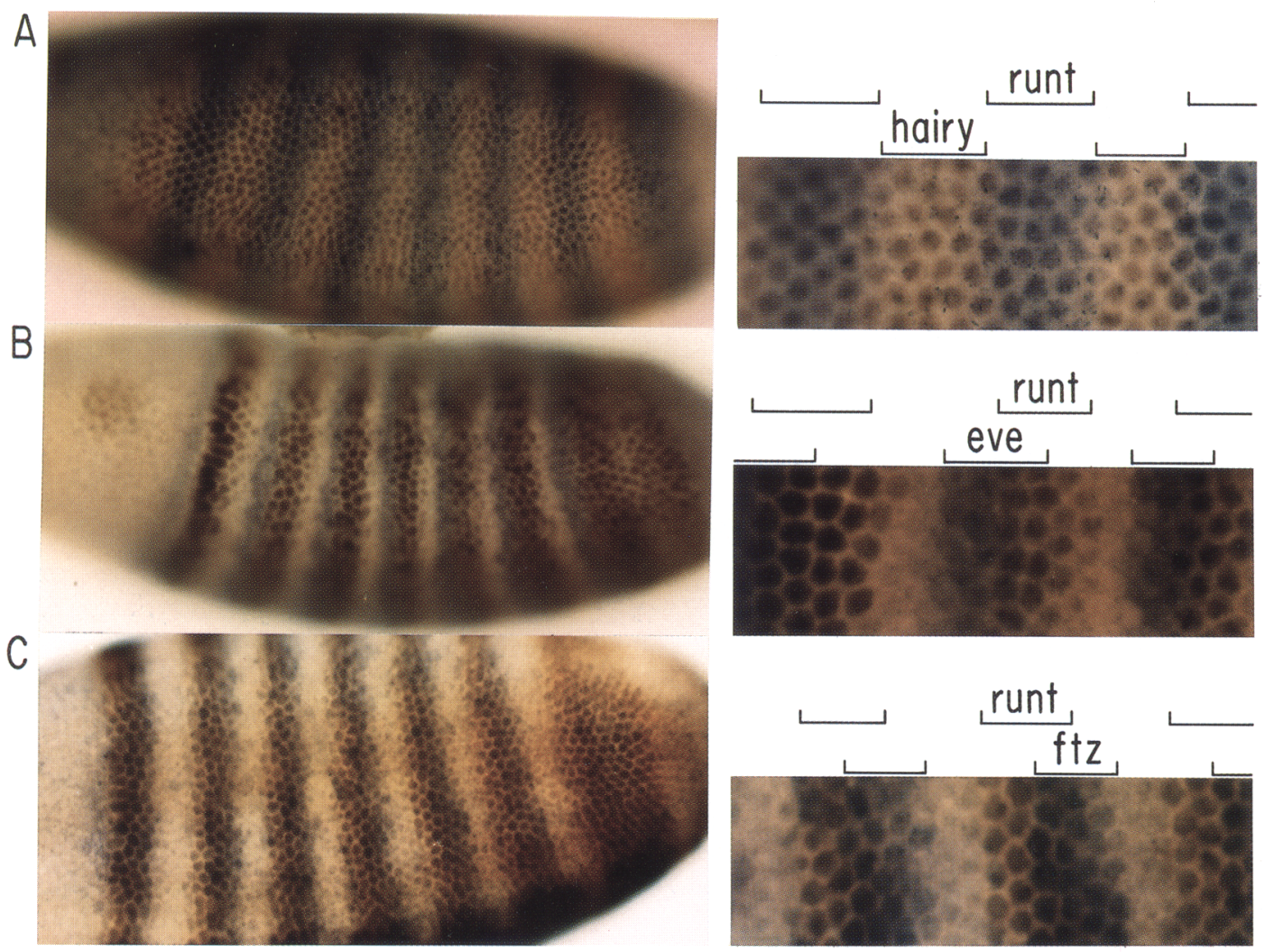

Figure 6. Phasing of patterns of pair-rule protein accumulation. Blastoderm-stage embryos double-stained with antibodies against runt and $h(A)$, eve $(B)$, and $f t z|C|$ are shown. $(A)$ runt accumulation is indicated by blue, and $h$ by brown. $(B$ and $C)$ The runt pattern is indicated by brown staining, and $e v e$ and $f t z$, respectively, are indicated by blue. An enlarged view of these patterns is shown at right of $(A-C)$. Our interpretation of the phasings of each of the other pair-rule genes relative to runt is indicated just above each enlargement. The $h$ antiserum is a rat polyclonal. The other antisera are all rabbit polyclonals. (For details of the double-staining protocols, see Materials and methods.)

tering this pathway but, instead, differentiate into epidermoblasts. When this regulation is removed, other cells in the equivalence group with the potential to become runt-expressing neuroblasts do so.

\section{Discussion}

\section{Function of the runt protein}

We determined the sequence of the Drosophila segmentation gene runt. Antibodies raised against the ORF deduced from this sequence recognize a nuclear protein that shows the anticipated pair-rule pattern of expression at the blastoderm stage. The regulation of the pairrule genes eve, ftz, and $h$ depends on runt function (Carroll and Scott 1986; Frasch and Levine 1987; Ingham and Gergen 1988). Investigations of the cis-regulatory regions of all three of these genes (Hiromi and Gehring 1987; Howard et al. 1988; Dearolf et al. 1989; Goto et al. 1989; Harding et al. 1989; Hooper et al. 1989), as well as RNA-labeling experiments (Edgar and Schubiger 1986; Edgar et al. 1986), indicate that significant aspects of the regulation of these genes are mediated at the level of transcription. Given these observations, we might expect runt to encode some type of transcriptional regula- tory protein. This expectation is consistent with the observed nuclear localization of the protein.

The sequence of the runt protein provides no obvious clues as to how it might be involved in transcriptional regulation. It does not contain one of the known types of DNA-binding domains nor does it contain one of the recognized protein-protein interaction motifs for transcriptional regulatory proteins. This stands in dramatic contrast to other segmentation genes that act at the blastoderm stage (Table 1). The products of three of the gap genes contain zinc finger DNA-binding motifs (Rosenberg et al. 1986; Tautz et al. 1987; Nauber et al. 1988). Among the pair-rule genes, the eve, ftz, and prd proteins all contain a DNA-binding homeo domain (Laughon and Scott 1984; Macdonald et al. 1986; Frigerio et al. 1986; Frasch et al. 1987). The pair-rule gene $h$, which, like runt, also plays a key role in regulating other pair-rule genes, is a member of the helix-loophelix family of transcription factors (Rushlow et al. 1989). If runt plays a direct role in regulating transcription, it would therefore represent a novel type of regulatory protein within the segmentation gene hierarchy.

There are several examples of DNA-binding transcriptional regulatory proteins for which no identifiable 


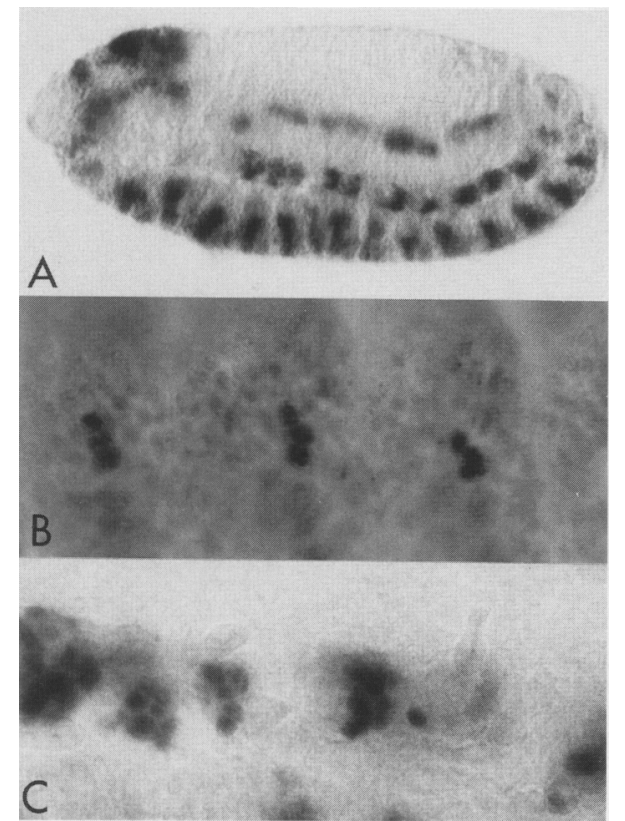

Figure 7. Influence of the Notch mutation on runt expression. (A) Lateral view of a germ-band-retracted embryo mutant for Notch and stained with runt antisera. Enlarged views of the runt staining pattern in a region corresponding to the $\mathrm{V}^{\prime}$ cluster of PNS neurons in the first few abdominal segments of a wildtype and a Notch ${ }^{X 286}$ embryo are shown in $B$ and $C$. The runtexpressing $\mathrm{V}^{\prime}$ cells in this mutant embryo are not all in the same focal plane. These clusters contain from $12-18$ cells.

structural motif has yet been defined. In a recent review on transcriptional regulatory proteins, nine transcription factors fell into this category (Johnson and McKnight 1989). However, a feature that is common to all of these proteins, as well as to the other characterized gap and pair-rule proteins (Table 1), is the presence of regions containing clusters of basic residues /a cluster of basic residues being defined as a region containing three basic residues within a 5-amino-acid stretch). Most of these proteins contain multiple clusters of basic residues (mean $=4$ ). In contrast, there are no regions in the runt protein where three basic residues are clustered within a 5-amino-acid stretch. The basic regions of transcription factors have been implicated as playing roles in DNA binding. The original motif defined for the helix-loophelix family of proteins contains a basic region that is required for DNA binding in in vitro assays (Davis et al. 1990). Similarly, multiple basic clusters are present in the conserved DNA-binding homeo box domain. Basic regions have also been implicated as the nuclear targeting signals for several proteins (for review, see Roberts 1989). The lack of clusters of basic residues in the runt protein provides a suggestion that it might not be a DNA-binding protein. The lack of an obvious nuclear targeting signal also raises the question of how the runt protein gets into the nucleus.

An unusual aspect of the runt protein, especially in light of its nuclear localization, is the prediction that it has an amino-terminal signal sequence that could target it for translocation across the membrane of the endoplasmic reticulum. As pointed out above, the amino acid composition of this signal sequence is unusual in that it contains a homopolymeric run of alanines. Preliminary in vitro translation/translocation experiments with dog pancreas microsomes indicate that the protein encoded by the runt ORF has the potential to enter the secretory pathway (A.S. Bonner and J.P. Duffy, unpubl.). In these experiments, the translocated form of the protein was also apparently modified by the addition of aminolinked carbohydrate. Further biochemical characterization of the bona fide, in vivo protein is required to determine the relevance of these observations to the localization and function of the runt protein.

Analysis of the runt sequence reveals other potentially significant characteristics. There are two "good" and five "poor" PEST regions in the runt protein. The occurrence of PEST regions has been correlated with proteins that are turned over rapidly (Rogers et al. 1986). All of the pair-rule proteins contain at least one good PEST region (Table 1), and for those cases examined, these proteins all seem to be turned over fairly rapidly. The runt protein also contains a putative ATP-binding site. A proposed consensus motif for ATP-binding sites is comprised of two regions (Walker et al. 1982). The first region, or A box, consists of a glycine-rich region that forms a $\beta$-turn and brings a lysine residue into contact with negatively charged phosphates of ATP. A perfect match to this consensus is found in residues 193-200 of the runt sequence (Fig. 3). The B box consists of four consecutive hydrophobic residues, followed by an aspartic acid. A potential match to this is found at positions 252-256 (Fig. 3). Nucleotide-binding domains also frequently contain several $\beta$-strands, which are thought to form a stable hydrophobic binding pocket (Bradley et al. 1987). Secondary structure predictions indicate five potential $\beta$-strands in the putative runt ATP-binding site. One is just before the glycine-rich $A$ box, and the other four occur within the next 60 residues (three before and one after the B box). Although the consensus motif for ATP-binding domains is not absolutely predictive, these several observations suggest that runt has the potential to be an ATP-binding protein. In this regard, it is worth noting that runt does not have homology to the related (and more predictive) consensus motifs that exist for either GTP-binding proteins or protein kinases.

\section{Pattern of runt expression}

The blastoderm expression pattern of the runt protein is consistent with expectations from analysis of RNA expression (Gergen and Butler 1988). We found the protein to be expressed in a pattern complementary to that of the pair-rule gene $h$. This phasing agrees well with the interpretation that these two genes play complementary and mutually antagonistic roles in regulating the expression of each other and the other pair-rule genes (Frasch and Levine 1987; Ingham and Gergen 1988; Carroll and Vavra 1989). We found that the stripes of runt accumulation overlap with the posterior half of each eve stripe, and the anterior half of each $f t z$ stripe. Once the 
Table 1. Features of segmentation proteins

\begin{tabular}{|c|c|c|c|c|}
\hline & \multirow{2}{*}{$\begin{array}{l}\text { Transcription } \\
\text { factor motif }\end{array}$} & \multirow{2}{*}{$\begin{array}{l}\text { Number of } \\
\text { clusters of } \\
\text { basic residues }\end{array}$} & \multicolumn{2}{|c|}{ PEST regions } \\
\hline & & & good & poor \\
\hline \multicolumn{5}{|l|}{ Gap genes } \\
\hline Krüppel & zinc fingers $(4)$ & 4 & 0 & 3 \\
\hline hunchback & zinc fingers $(6)$ & 3 & 2 & 8 \\
\hline knirps & zinc fingers $(2)$ & 5 & 0 & 5 \\
\hline giant & leucine zipper & 5 & 1 & 2 \\
\hline \multicolumn{5}{|l|}{ Pair-rule genes } \\
\hline even-skipped & homeo box & 3 & 3 & 5 \\
\hline fushi tarazu & homeo box & 5 & 2 & 7 \\
\hline hairy & helix-loop-helix & 3 & 1 & 2 \\
\hline paired & homeo box & 2 & 1 & 6 \\
\hline runt & - & 0 & 2 & 5 \\
\hline
\end{tabular}

This table was compiled by analyzing available sequence data. The references are Rosenberg et al. (1986) (Kr); Tautz et al. (1987) (hb); Nauber et al. (1988) (kni); B. Eldon and V. Pirrotta (pers. comm.) (gt); Macdonald et al. (1986) (eve); Laughon and Scott (1984) (ftz); Rushlow et al. (1989) (h); and Frigerio et al. (1986) (prd). Clusters of basic residues were defined as regions where at least three of five consecutive residues are basic (i.e., either lysine or arginine). PEST regions were identified and scored as good or poor by using the PESTFIND program in the PC/GENE sequence analysis package. This program utilizes the original PEST algorithim of Rogers et al. (1986). The selection parameters specified minimal regions of 10 residues containing at least one proline, one glutamic or aspartic acid, and one serine or threonine. Good PEST regions have scores of 5 or better.

initial four-cell-wide stripes of $e v e$ and $f t z$ are established, they evolve rapidly by narrowing. This occurs by the elimination of expression in the more posterior rows of cells in each stripe. Our results show that those cells that lose eve expression are also those that express runt. This is exactly what is expected given the negative regulatory effect that runt has on eve expression (Frasch and Levine 1987; Ingham and Gergen 1988). Our results indicate a reciprocal role for runt in the regulation of $f t z$. The cells in the anterior region of each $f t z$ stripe, in which the expression of $f t z$ perdures, are those that express runt. The regulatory effects of runt could be direct, or they could be indirect and due to the repressing effects of runt on $h$. In this paper, we show that this gene is normally expressed in a pattern complementary to runt. It is negatively regulated by runt (Ingham and Gergen 1988/ and regulates both $f t z$ and eve in a manner reciprocal to runt. Elucidation of the mechanisms of these regulatory effects requires more knowledge on the function of runt.

We found that the runt protein is expressed throughout embryogenesis. The protein is expressed in both the CNS and the PNS. Several other segmentation proteins have also been found to be re-expressed in the embryonic nervous system (Carroll and Scott 1985; DiNardo et al. 1985; Frasch et al. 1987; Gaul et al. 1987). For the pair-rule proteins eve and $f t z$, there is evidence that this expression plays a role in the specification of neural cell fates (Doe et al. 1988a,b). The extensive neural expression of runt suggests that it may play an important role in the developing nervous system. This suggestion is supported by experiments with a runt temperature-sensitive allele, which indicate that runt is involved in regulating the expression of eve in the CNS (J.B. Duffy and J.P. Gergen, unpubl.). These observations are particularly intriguing in the context of the recent hypothesis that the neural functions of the Drosophila segmentation genes are the ancestral ones that have been conserved throughout evolution (Patel et al. 1989). This suggests that investigating the function of the runt protein and the mechanism by which it regulates the expression of other genes will have significance beyond contributing to our understanding of the formation of body pattern in the early Drosophila embryo.

\section{Materials and methods}

\section{Plasmid DNAs}

The three original runt cDNA clones (D1, E20, and E25) were isolated from libraries provided by the laboratory of $\mathrm{T}$. Kornberg (University of California, San Francisco; see Poole et al. 1985). The composite cDNA referred to as ED was constructed by joining a fragment that corresponds to the $5^{\prime}$ end of the mRNA from clone D1 to a fragment that corresponds to the $3^{\prime}$ end of the mRNA from clone E20. These two fragments were joined at a unique $X$ hol site present in their region of overlap (map position 492 in Fig. 3). The construct used to generate the runt- $\beta$ galactosidase fusion protein used for immunization was made by cloning an ORF-spanning fragment of the E25 cDNA into the pWR590-1 vector (Guo et al. 1984). Sequences from the region corresponding to the 5 '-untranslated leader were removed by using oligonucleotide-site-directed mutagenesis to insert a BamHI recognition site starting 9 nucleotides upstream of the ATG at the beginning of the runt ORF. A T7 expression system (Studier and Moffatt 1986) was used to express a nonfusion form of the runt protein in bacteria. Site-directed mutagenesis was used to create an NdeI cleavage site at the position of the first ATG in the E25 and ED cDNAs. These ORFs were then cloned into the pT7-7 expression vector using this site (S. Tabor, pers. comm.; see Tabor and Richardson 1985).

A nested set of unidirectional deletions were generated for sequencing, using the exonuclease III/mung bean nuclease strategy (Henikoff 1984; Stratgene kit). Deletion series were made from both ends of cDNA E20 and from the $5^{\prime}$ end of 
cDNA D1. The genomic DNA clone used for S1 nuclease protection contained an $8.5-\mathrm{kb}$ fragment extending from a $B a m H I$ site, $2.5 \mathrm{~kb}$ upstream of the transcription unit, to a downstream HindIII site. Genomic sequence information was obtained from this template and/or subcloned derivatives of it.

\section{Nucleic acid manipulation}

Isolation of plasmid DNAs, restriction digestions, and analytical and preparative gels were all done under standard conditions (Maniatis et al. 1982). Sl nuclease protection experiments were done essentially according to Maniatis et al. (1982). Hybridizations were done with $1 \mu \mathrm{g}$ of the cloned genomic DNA and $5 \mu \mathrm{g}$ of poly $(\mathrm{A})^{+}$RNA from 2- to 4 -hr-old Drosophila embryos. This RNA was isolated as described in Gergen and Butler (1988). After hybridization, the reactions were diluted into digestion buffer containing S1 nuclease, at $108 \mathrm{U} / \mathrm{ml}$ final (Bethesda Research Laboratories, BRL), and incubated at $30^{\circ} \mathrm{C}$ for $30 \mathrm{~min}$. The protected fragments were collected by ethanol precipitation, electrophoresed on denaturing, alkaline agarose gels, and detected by Southern blotting (Maniatis et al. 1982). Primer extension was done according to Maniatis et al. (1982). The primer was the synthetic oligonucleotide 5'-TGCACTTCACTTTATCG- $3^{\prime}$. This sequence is complementary to the nucleotides extending from position +156 to position +172 of Figure 3. The oligonucleotide was end-labeled with ${ }^{32} \mathrm{P}$ using T4 polynucleotide kinase (Boehringer Mannheim). The annealing reaction contained $10 \mu \mathrm{g}$ of poly $(\mathrm{A})^{+}$RNA from 2- to 4-hr embryos and $50 \mathrm{ng}$ of labeled oligonucleotide. DNA sequence determination was done by using the dideoxy chain-termination method and Sequenase (U.S. Biochemical). The initial sequencing data were obtained by using the nested set of cDNA deletion derivatives described above. This initial sequence information was verified, and the sequence of CDNA E25 and the genomic clones was obtained with a set of synthetic oligonucleotide sequencing primers spaced at $\sim 200$ bp across the initially sequenced interval. Details are available upon request.

\section{DNA sequence analysis}

The PCGENE sequence analysis package was used for analysis. Homology searches were done by using the FASTP algorithm with this package and the Compact Disc version of the Swiss Protein Data Base (release $11 ; 10,856$ sequences). Homology searches were also done on the NBRF data base $\{12,476$ sequences), using the WORDSEARCH program in the University of Wisconsin Computer Group Package. The putative signal sequence at the amino terminus was identified by the PSIGNAL PC/GENE program, which uses an algorithm of von Heijne (1986). The runt sequence had a score of 6.45 . This is above the cutoff value of 3 . In von Heijne's initial test of this algorithm, all of 132 nonsecreted proteins had scores below 4. PEST regions were identified by using the PC/GENE PESTFIND program. The two good PEST regions identified in the runt sequence had scores of 13.68 and 8.38 , using the algorithm of Rogers et al. (1986).

\section{Immunization and antibody purification}

Four young male rabbits (New Zealand) were immunized with $200 \mu \mathrm{g}$ of gel-purified pWR/runt protein emulsified in complete Freund's adjuvant. Subsequent monthly boosts were done with the same amount of antigen in incomplete adjuvant. Serum was collected 10 days after a boost. One rabbit gave a useful immune response (staining of embryos with a $1: 25$ dilution of sera) after the fifth boost. Affinity purification of antibodies from this sera was required to reduce nonspecific background staining. The procedure used for affinity purification was adapted from Guerriero et al. (1986). Purified nonfusion-runt protein made with the $\mathrm{T} 7$ expression system was spotted onto nitrocellulose and dried. Filters were blocked in Blotto [50 mM Tris $(\mathrm{pH} 7.5), 0.9 \% \mathrm{NaCl}, 0.05 \%$ Tween $20,3 \%$ Carnation nonfat dry milk powder, $0.05 \%$ sodium azide], and rinsed in TBS plus sodium azide [TBS is $20 \mathrm{~mm}$ Tris (pH 7.5), $500 \mathrm{~mm}$ $\mathrm{NaCl}$. Rabbit serum was diluted $1: 1$ in TBS and incubated with the filter overnight at $4^{\circ} \mathrm{C}$ with gentle agitation. Nonspecifically bound antibodies were removed with several washes of TBS over a 2-hr period at room temperature. runt-specific antibodies were eluted from the filter by washing it in $0.5 \mathrm{ml}$ of 0.1 $\mathrm{M}$ glycine ( $\mathrm{pH}$ 2.7) and $75 \mathrm{~mm} \mathrm{NaCl}$ for $2 \mathrm{~min}$. This eluant was pooled with the eluant from one subsequent wash of the filter with $6 \mathrm{mg} / \mathrm{ml} \mathrm{BSA}$ and dialyzed against TBS at $4^{\circ} \mathrm{C}$. Affinity-purified antibody was used undiluted for immunohistochemistry.

The $h$ antibody was obtained from Ken Howard and Gary Struhl /Columbia College of Physicians and Surgeons, New York). This polyclonal serum was generated in rats and used at a $1: 200$ dilution. The eve antibody was obtained from Manfred Frasch (Max Planck Institut für Entwicklungsbiologie, Tübingen). This rabbit polyclonal was used at a dilution of $1: 10,000$. The $f t z$ antibody was obtained from Henry Krause (Banting and Best Institute, Toronto) and was used at a dilution of $1: 800$. The lamin antibody was provided by Paul Fisher (SUNY at Stony Brook, New York) and was used at a dilution of $1: 500$. The biotin conjugated anti-rabbit IgG (Vector labs) and anti-rat IgG (Sigma) antibodies were used at $5 \mu \mathrm{g} / \mathrm{ml}$. The alkaline phosphatase-conjugated anti-rabbit IgG antibody (Jackson) was used at $2 \mu \mathrm{g} / \mathrm{ml}$. All secondary antibodies were preadsorbed against random embryos at twice the concentrations listed above.

\section{Drosophila embryos and immunohistochemistry}

The wild-type embryos were from a stock homozygous for yellow and white ${ }^{67 c 23}$. runt ${ }^{L B 5}$ embryos were collected from a stock in which the FM7 X-chromosome balancer carries a Ptransposon that expresses $\beta$-galactosidase under the control of the $f t z$ promoter. This chromosome was generated by use of 82-3 (Robertson et al. 1988) to move ftz/lacC transposons (Hiromi et al. 1985) onto FM7c. In this stock, the male embryos mutant for runt are the only embryos that do not express $\beta$-galactosidase in the typical $\mathrm{ftz}$ pattern. Therefore, the mutant runt embryos can be identified unambiguously by double staining with antibodies against $\beta$-galactosidase. Because of the stability of the $\beta$-galactosidase protein in the embryo, this marker is useful for all stages of embryogenesis subsequent to the initial appearance of the $\mathrm{ftz} / \mathrm{lacC}$ pattern at the late cellular blastoderm stage. The runt ${ }^{L B 5}$ mutation is a null allele that produces no transcript (Gergen and Butler 1988). The Notch ${ }^{\text {XL86 }}$ mutation is an embryonic lethal allele with an intermediate phenotype. It was obtained from the stock collection at Princeton University.

Embryos for immunohistochemistry were permeabilized, fixed, and devitellinized, essentially as per Mitchison and Sedat (1983). The aqueous fixative phase was $4 \%$ in formaldehyde and contained $10 \mathrm{~mm}$ potassium phosphate (pH 6.8$), 45 \mathrm{mM} \mathrm{KCl}, 15$ $\mathrm{mM} \mathrm{NaCl}$, and $13 \mathrm{mM} \mathrm{MgCl}$. Fixed embryos were rehydrated in PBS $\left(137 \mathrm{mM} \mathrm{NaCl}, 3 \mathrm{mM} \mathrm{KCl}, 10 \mathrm{mM} \mathrm{Na}{ }_{2} \mathrm{HPO}_{4}, 2 \mathrm{~mm}\right.$ $\mathrm{KH}_{2} \mathrm{PO}_{4}$ ) and blocked with $2 \%$ goat serum (Cappel) in PBS for $30 \mathrm{~min}$ at room temperature. Primary antibody was diluted in PBS/MT (PBS containing $1 \%$ milk powder and $0.1 \%$ Tween 80 ) and incubated with embryos either for $4 \mathrm{hr}$ at room temperature or overnight at $4^{\circ} \mathrm{C}$. Embryos were then washed 10 times with $0.4 \mathrm{ml}$ of PBS/MT and incubated with preadsorbed sec- 
ondary antibodies for either $2 \mathrm{hr}$ at room temperature or overnight at $4^{\circ} \mathrm{C}$. After this incubation, the embryos were washed 10 times in PBS/T (PBS plus $0.1 \%$ Tween 80 ). The HRP (Horseradish peroxidase) version of the Vectastain kit (Vector) was used with biotinylated secondary antibodies to obtain brown immunohistochemical staining signals. The biotinylated HRP/ Avidin-DH complex was formed according to the supplier's protocol and incubated with the relevant embryos for $30 \mathrm{~min}$. After 10 washes in PBS/T, the embryos were postfixed for 10 min in ethanol and rehydrated in HRP buffer $[50 \mathrm{~mm}$ citric acid, $50 \mathrm{~mm}$ ammonium acetate ( $\mathrm{pH}$ 5.0)]. The first step of this rehydration was done in $1: 1$ ethanol/HRP buffer. Embryos were stained in HRP buffer containing $2.7 \mathrm{mg} / \mathrm{ml}$ diaminobenzidine, $0.02 \% \mathrm{NiCl}_{2}$ and $\mathrm{CoCl}_{2}$, and $0.006 \%$ hydrogen peroxide. The staining reaction was stopped by addition of sodium azide to $2 \%$. Prior to mounting, the embryos were washed in PBS plus azide, dehydrated in ethanol, cleared in Histoclear (National Diagnostics), and mounted in either Histomount (National Diagnostics/ or Permount.

The procedure for double staining embryos was adapted from a protocol provided by Nipam Patel (University of California, Berkeley). Embryos were fixed and rehydrated as above and then blocked in PBT $+\mathrm{N}(0.2 \%$ BSA, $0.1 \%$ Triton $\mathrm{X}-100,0.5 \%$ goat serum in PBS). When the primary antibodies were derived from different species (i.e., runt $-h$ double), they were simultaneously incubated with the embryos in PBT $+\mathrm{N}$. In this case, after washing the embryos as above, the two secondaries were then also incubated simultaneously with the embryos. The HRP color reaction was done first. The embryos were incubated for $10 \mathrm{~min}$ in PBT containing $0.3 \mathrm{mg} / \mathrm{ml}$ diaminobenzidine. Hydrogen peroxide was then added to $0.01 \%$ to start the staining reaction. After development of the HRP color reaction, the embryos were rinsed in PBT and transferred to AP buffer [100 mM NaCl, $5 \mathrm{~mm} \mathrm{MgCl}_{2}, 100 \mathrm{~mm}$ Tris (pH 9.5), $0.1 \%$ Tween 20, $1 \mathrm{~mm}$ levamisole]. The alkaline phosphatase color reaction was started by adding the B-CIP and X-phosphate substrates (Boehringer). In the cases where the two primary antibodies were from the same species, the antibody to be visualized with HRP was carried through the entire staining procedure. The embryos were then reblocked, as described above, and the entire set of incubations was repeated with the other antibody and the AP staining protocol.

\section{Acknowledgments}

The generous gifts of antibodies by Paul Fisher, Manfred Frasch, Ken Howard, and Henry Krause are greatly appreciated. We acknowledge the invaluable technical assistance of Clare Bolduc (Houston) and Margaret Roberge (Stony Brook). Several members of the M.D. Anderson Department of Biochemistry and Molecular Biology were helpful in getting us started with protein chemistry and immunochemistry. The assistance of Howard Kaplan was especially appreciated. This manuscript was improved by thoughtful comments from Stan Fields, Barbara Butler, Martin Klingler, Zuzanna Zachar, and Gail Mandel. Alisha Tizenor graciously and efficiently provided Figure 3. Oligonucleotides were synthesized on a core facility supported by grants from The National Institutes of Health (NIH). J.D. was partially supported as a predoctoral trainee on an $\mathrm{NIH}$ training grant. This research was supported by a grant from NIH (R01-HD22448) and by an NIH Biomedical Research Support grant (RR5511-25).

Sequence data described in this paper have been submitted to EMBL/GenBank data libraries.

The publication costs of this article were defrayed in part by payment of page charges. This article must therefore be hereby marked "advertisement" in accordance with 18 USC section 1734 solely to indicate this fact.

\section{References}

Bradley, M.K., T.F. Smith, R.H. Lathrop, D.M. Livingston, and T.A. Webster. 1987. Consensus topography in the ATP binding site of the simian virus 40 and polyomavirus large tumor antigens. Proc. Natl. Acad. Sci. 84: 4026-4030.

Carroll, S.B. and M.P. Scott. 1985. Localization of the fushi tarazu protein during Drosophila embryogenesis. Cell 43: $47-57$.

- 7 1986. Zygotically active genes that affect the spatial expression of the fushi tarazu segmentation gene during early Drosophila embryogenesis. Cell 45: 113-126.

Carroll, S.B. and S.H. Vavra. 1989. The zygotic control of Drosophila pair-rule gene expression II. Spatial repression by gap and pair-rule gene products. Development 107: 673-683.

Carroll, S.B., A. Laughon, and B.S. Thalley. 1988. Expression, function, and regulation of the hairy segmentation protein in the Drosophila embryo. Genes Dev. 2: 883-890.

Davis, R.L., P.-F. Cheng, A.B. Lassar, and H. Weintraub. 1990. The MyoD DNA binding domain contains a recognition code for muscle-specific gene activation. Cell 60: 733-746.

Dearolf, C.R., J. Topol, and C.S. Parker. 1989. Transcriptional control of Drosophila fushi tarazu zebra stripe expression. Genes Dev. 3: 384-398.

Desplan, C., I. Theis, and P.H. O'Farrell. 1988. The sequence specificity of homeodomain-DNA interaction. Cell 54: $1081-1090$

DiNardo, S. and P.H. O'Farrell. 1987. Establishment and refinement of segmental pattern in the Drosophila embryo: Spatial control of engrailed expression by pair-rule genes. Genes Dev. 1: 1212-1225.

DiNardo, S., J.M. Kuner, J. Theis, and P.H. O'Farrell. 1985. Development of embryonic pattern in $\mathrm{D}$. melanogaster as revealed by accumulation of the nuclear engrailed protein. Cell 43: 59-69.

Doe, C.Q., D. Smouse, and C.S. Goodman. 1988a. Control of neuronal fate by the Drosophila segmentation gene evenskipped. Nature 333: 376-378.

Doe, C.Q., Y. Hiromi, W.J. Gehring, and C.S. Goodman. 1988b. Expression and function of the segmentation gene fushi tarazu during Drosophila neurogenesis. Science 239: 170175.

Edgar, B.A. and G. Schubiger. 1986. Parameters controlling transcriptional activation during early Drosophila development. Cell 44: 871-877.

Edgar, B.A., M.P. Weir, G. Schubiger, and T. Kornberg. 1986. Repression and turnover pattern fushi tarazu RNA in the early Drosophila embryo. Cell 47: 747-754.

Fitzpatrick, V.D. and C.J. Ingles. 1989. The Drosophila fushi tarazu polypeptide is a DNA-binding transcriptional activator in yeast cells. Nature 337: 666-668.

Frasch, M. and M. Levine. 1987. Complementary patterns of even-skipped and fushi tarazu expression involve their differential regulation by a common set of segmentation genes in Drosophila. Genes Dev. 1: 981-995.

Frasch, M., T. Hoey, C. Rushlow, H. Doyle, and M. Levine. 1987. Characterization and localization of the even-skipped protein of Drosophila. EMBO I. 6: 749-759.

Frigerio, G., M. Burri, D. Bopp, S. Baumgartner, and M. Noll. 1986. Structure of the segmentation gene paired and the Drosophila PRD gene set as part of a gene network. Cell 47: 735-746.

Gaul, U., E. Seifert, R. Schuh, and H. Jäckle. 1987. Analysis of 
Krüppel protein distribution during early Drosophila development reveals posttranscriptional regulation. Cell 50: $639-647$.

Gergen, J.P. and B.A. Butler. 1988. Isolation of the Drosophila segmentation gene runt and analysis of its expression during embryogenesis. Genes Dev. 2: 1179-1193.

Goto, T., P. Macdonald, and T. Maniatis. 1989. Early and late periodic patterns of even-skipped expression are controlled by distinct regulatory elements that respond to different spatial cues. Cell 57: 413-422.

Guerriero, V., M.A. Russo, N.J. Olson, J.A. Putkey, and A.R. Means. 1986. Domain organization of chicken gizzard myosin light chain kinase deduced from a cloned cDNA. Biochemistry 25: 8372-8381.

Guo, L.-H., P.P. Stepien, J.Y. Tso, R. Brosseau, S. Narang, D.Y. Thomas, and R. Wu. 1984. Synthesis of human insulin gene. VIII. Construction of expression vectors for fused proinsulin production in Escherichia coli. Gene 29: 251-254

Harding, K., T. Hoey, R. Warrior, and M. Levine. 1989. Autoregulatory and gap response elements of the even-skipped promoter of Drosophila. EMBO I. 8: 1205-1212.

Henikoff, S. 1984. Unidirectional digestion with exonuclease III creates targeted breakpoints for DNA sequencing. Gene 28: $351-359$.

Hiromi, Y. and W.J. Gehring. 1987. Regulation and function of the Drosophila segmentation gene fushi tarazu. Cell 50: $963-974$.

Hiromi, Y., A. Kuroiwa, and W.J. Gehring. 1985. Control elements of the Drosophila segmentation gene fushi tarazu. Cell 43: 603-613.

Hoey, T. and M. Levine. 1988. Divergent homeo box proteins recognize similar DNA sequences in Drosophila. Nature 332: 858-861.

Hooper, K.L., S.M. Parkhurst, and D. Ish-Horowicz. 1989. Spatial control of hairy protein expression during embryogenesis. Development 107: 489-504.

Howard, K. and P. Ingham. 1986. Regulatory interactions between the segmentation genes fushi tarazu, hairy, and engrailed in the Drosophila blastoderm. Cell 44: 949-957.

Howard, K., P. Ingham, and C. Rushlow. 1988. Region-specific alleles of the Drosophila segmentation gene hairy. Genes Dev. 2: $1037-1046$.

Hultmark, D., R. Klemenz, and W.J. Gehring. 1986. Translational and transcriptional control elements in the untranslated leader of the heat-shock gene hsp22. Cell 44: 429438.

Ingham, P. and P. Gergen. 1988. Interactions between the pairrule genes runt, hairy, even-skipped and fushi tarazu and the establishment of periodoc pattern in the Drosophila embryo. Development 104(Suppl.): 51-60.

Jäckle, H., D. Tautz, R. Schuh, E. Seifert, and R. Lehmann. 1986. Cross-regulatory interactions among the gap genes of Drosophila. Nature 324: :668-670.

Jaynes, J.B. and P.H. O'Farrell. 1988. Activation and repression of transcription by homeodomain-containing proteins that bind a common site. Nature 336: 744-749.

Johnson, P.F. and S.L. McKnight. 1989. Eukaryotic transcriptional regulatory proteins. Annu. Rev. Biochem. 58: 799839.

Krause, H.M., R. Klemenz, and W.J. Gehring. 1988. Expression, modification, and localization of the fushi tarazu protein in Drosophila embryos. Genes Dev. 2: 1021-1036.

Laughon, A. and M.P. Scott. 1984. Sequence of a Drosophila segmentation gene: Protein structure homology with DNAbinding proteins. Nature 310: 25-31.

Macdonald, P.M., P. Ingham, and G. Struhl. 1986. Isolation, structure, and expression of even-skipped: A second pairrule gene of Drosophila containing a homeo box. Cell 47: $721-734$.

Maniatis, T., E.F. Fritsch, and I. Sambrook. 1982. Molecular cloning: A laboratory manual. Cold Spring Harbor Laboratory, Cold Spring Harbor, New York.

Mitchison, T.J. and J. Sedat. 1983. Localization of antigenic determinants in Drosophila embryos. Dev. Biol. 99: 261-264.

Mohler, J., E.D. Eldon, and V. Pirrotta. 1989. A novel spatial transcription pattern associated with the segmentation gene giant of Drosophila. EMBO I. 8: 1539-1548.

Mount, S.M. 1982. A catalogue of splice junction sequences. Nucleic Acids Res. 10: 459-472.

Nauber, U., M.J. Pankratz, A. Kienlin, E. Seifert, U. Klemm, and H. Jäckle. 1988. Abdominal segmentation of the Drosophila embryo requires a hormone receptor-like protein encoded by the gap gene knirps. Nature 336: 489-492.

Ollo, R. and T. Maniatis. 1987. Drosophila Krüppel gene product produced in a baculovirus expression system is a nuclear phosphoprotein that binds to DNA. Proc. Natl. Acad. Sci. 84: 5700-5704.

Pankratz, M.J., M. Hoch, E. Seifert, and H. Jäckle. 1989. Krüppel requirements for knirps enhancement reflects overlapping gap gene activities in the Drosophila embryo. Nature 341: :337-340.

Pankratz, M.J., E. Seifert, N. Gerwin, B. Billi, U. Nauber, and H. Jäckle. 1990. Gradients of Krüppel and knirps gene products direct pair-rule gene stripe patterning in the posterior region of the Drosophila embryo. Cell 61: 309-317.

Patel, N.H., E. Martin-Blanco, K.G. Coleman, S.J. Poole, M.C. Ellis, T.B. Kornberg, and C.S. Goodman. 1989. Expression of engrailed proteins in arthropods, annelids and chordates. Cell 58: 955-968.

Poole, S.J., L.M. Kauvar, B. Drees, and T. Kornberg. 1985. The engrailed locus of Drosophila: Structural analysis of an embryonic transcript. Cell 40: 37-43.

Roberts, B. 1989. Nuclear location signal-mediated protein transport. Biochim. Biophys. Acta 1008: 263-280.

Robertson, H.M., C.R. Preston, R.W. Phillis, D.M. JohnsonSchlitz, W.K. Benz, and W.R. Engels. 1988. A stable source of $P$ element transposase in Drosophila melanogaster. Genetics 118: 461-470.

Rogers, S., R. Wells, and M. Rechsteiner. 1986. Amino acid sequences common to rapidly degraded proteins: The PEST hypothesis. Science 234: 364-368.

Rosenberg, U.B., C. Schroder, A. Preiss, A. Kienlin, S. Cote, I. Riede, and H. Jäckle. 1986. Structural homology of the product of the Drosophila Krüppel gene with Xenopus transcription factor IIIA. "Nature 319: 336-339.

Rushlow, C.A., A. Hogan, S.M. Pinchin, K.M. Howe, M Lardelli, and D. Ish-Horowicz. 1989. The Drosophila hairy protein acts both in segmentation and bristle patterning and shows homology to N-myc. EMBO J. 8: 3095-3103.

Stanojevic, D., T. Hoey, and M. Levine. 1989. Sequence-specific DNA-binding activities of the gap proteins encoded by hunchback and Krüppel in Drosophila. Nature 341: 331335.

Studier, F.W. and B.A. Moffatt. 1986. Use of bacteriophage T7 RNA polymerase to direct selective high-level expression of cloned genes. J. Mol. Biol. 189: 113-130.

Tabor, S. and C.C. Richardson. 1985. A bacteriophage T7 RNA polymerase/promoter system for controlled exclusive expression of specific genes. Proc. Natl. Acad. Sci. 82: 10741078.

Tautz, D., R. Lehmann, H. Schnurch, R. Schuh, E. Seifert, A. Kienlin, K. Jones, and H. Jäckle. 1987. Finger protein of 
novel structure encoded by hunchback, a second member of the gap class of Drosophila segmentation genes. Nature 327: 383-389.

Treisman, J. and C. Desplan. 1989. The products of the Drosophila gap genes hunchback and Krüppel bind to the hunchback promoters. Nature 341: 335-337.

Treisman, J., P. Gonczy, M. Vashishtha, E. Harris, and C. Desplan. 1989. A single amino acid can determine the DNA binding specificity of homeodomain proteins. Cell 59: 553562.

von Heijne, G. 1986. A new method for predicting signal sequence cleavage sites. Nucleic Acids Res. 14: 4683-4690.

Walker, J.E., M. Saraste, M.J. Runswick, and N.J. Gay. 1982. Distantly related sequences in the alpha- and beta- subunits of ATP synthase, myosin, kinases and other ATP-requiring enzymes and a common nucleotide binding fold. EMBO $I$. 1: $945-951$. 


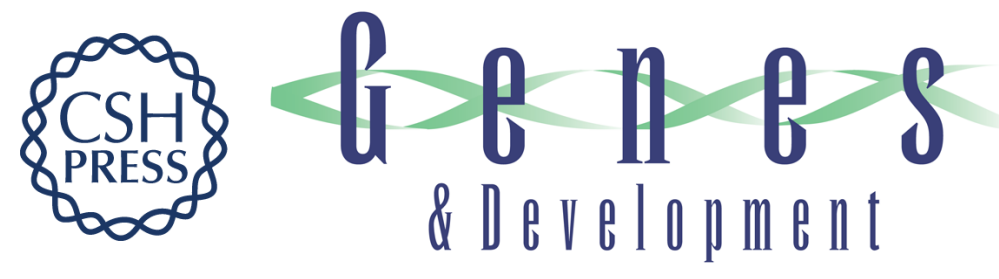

\section{The Drosophila segmentation gene runt encodes a novel nuclear regulatory protein that is also expressed in the developing nervous system.}

M A Kania, A S Bonner, J B Duffy, et al.

Genes Dev. 1990, 4:

Access the most recent version at doi:10.1101/gad.4.10.1701

References This article cites 61 articles, 16 of which can be accessed free at:

http://genesdev.cshlp.org/content/4/10/1701.full.html\#ref-list-1

License

Email Alerting Receive free email alerts when new articles cite this article - sign up in the box at the top Service right corner of the article or click here.

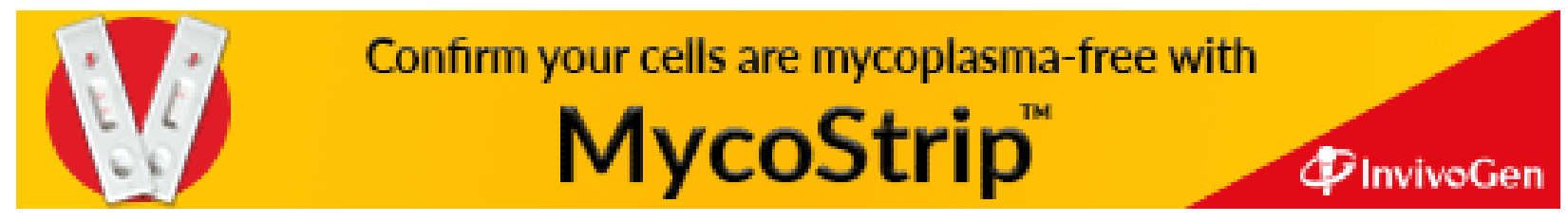

